\title{
Socio-Political Dynamics And The Clash Of Values In Nayantara Sahgal's This Time Of Morning
}

\author{
S.Prabhakaran, R.Lakshmi, Rangarajan, Sagunthala
}

\begin{abstract}
This present paper deals with the SocioPolitical changes and the clash of values encountered after independent India represented in Nayantara Sahgal's novel, This Time of Mornig. On the one hand, the study explores the conflicting attitude of idealism and pragmatism, humanism and non-humanism, and Gandhian Philosophy and Ganghian syndrome. The novel deals with the idealism of Kailas Virund, Prakash Sukla and Abdual Rahman is juxtaposed to the corrupt political system of Somnath, Hari Mohan and Kalyan. On the other hand, it deals with the problem of communication among the secluded elite of Delhi in term of artistic construct. The core theme of the novel is stated from the point of Rakesh who is himself uncertain vacillating anxious and hesitant at the beginning. Nita is another character who becomes susceptible to Kalyan's influence. In her we find a young woman whose desires ...both spiritual and sexual life have not been understood by her parents. Freedom is seen to be an indispensable prerequisite for human development. Every characters in this novel endeavour towards realization of freedom as basic human value. Sahgal's prime interest in this novel is perfect and proper relationship between in public life as well as personal life and she ardently shows the problems caused by a changing order.
\end{abstract}

Key Word-Idealism, Pragmatism, Gandhian Philosophy, Gandhian Syndrome, and Freedom.

\section{INTRODUCTION}

Nayantara Sahgal is the most distinguished Indo-Anglian novelist in the Independent India. Since she was born in one of the eminent and preeminent political family, it is not surprising that history and politics inspire and underlie in much of her writing. She has been deeply influenced by Gandhian principles, which is her social conscious of the period. This time of Morning is rich full novel and Sahgal handles a difficult objective well. In this novel the political and social issues are better fused than in her first novel, The Time to be Happy. The social and political spheres both show a preoccupation with the theme of identity and the saving of the society from the predatory individual.

In This Time of Morning, Nayantara Sahgal deals with the conflicting attitude of idealism and materialism in the Post-Independent India. Kailas Virand symbolises idealism and Kalyan symbolises pragmatism. People like Somnath may disapprove and discredit idealism as merely utopian

Revised Manuscript Received on April 19, 2019.

S.Prabhakaran, Research Scholar, R\&D Institute of Science and Technology, Avadi, Chennai, Tamilnadu, India.

Dr.R.Lakshmi, Research Guide, R\&D Institute of Science and Technology, Avadi, Chennai, Tamilnadu, India.

Rangarajan, Vel Tech, Velachery, Chennai, Tamil Nadu, India.

Dr. Sagunthala, R\&D Institute of Science and Technology, Avadi, Chennai, Tamilnadu, India. and hence impracticable in the present-day politics. But the novel shows that pursuing of materialism without a humanistic and ethical acclimation and orientation lead to oppression and exploitation as exemplified by the alliance, rather misalliance, between Hari Mohan and kalyan Singh. Such an alliance perils individual freedom and is seen to be deleterious and destructive to the development of the nation.

In its presentation of the power structures of the parliament and secretariat, This Time of Morning bears a close resemblance to C.P Snow's Corridors of Power. The high dream of political game plan and political stratagem contained in this novel is placed before us in terms of series of juxtaposed attitudes, orientations and values. The idealism of Kailas Virnd, Prakash Sukla and Abdul Rahmam is juxtaposed to the corrupt political systems of Somnath, Hari Mohan and Kalyan. The efficiency and dedication of Arjun Mitra in public life and his failure in personal life are contrasted with the corrupt practices, the immoral life of Dhiraj Singh. Arjun Mitra's wife and his affliction, Uma, who indulges in extra marital affair out of a sense of boredom, abomination against the dual moral codes adopted in judging men and women, is juxtaposed to Mira, affectionate and devoted wife of Kailas. If leela, during her stay in the United States, takes leeway like an uncaged bird and eventually ruins herself, Rashmi strives to acquire the freedom of self-expression. Tough her interlude of sex with Berenson, the architect of Gandhian Peace Institute, corroborates abortive, she is hopeful of rebuilding a significant and meaningful relationship with Rakesh. Unequivocally the freedom that she has acquired will rejuvenate and reinvigorate her life. Thus the novel is peopled with politicians of every description, artists, highly placed and influenced bureaucrats, parliamentarians, journalists, and gossiping, liberated lecherous society women as well as traditionally educated house wives. Sahgal's canvas is so large as to include the whole of the sophisticated and cultured urban cultural world of modern Delhi. Critics like Kai Nicholson and Lois Martley regard this novel as "a sociological study of urban characters in contemporary India, rather than a work of literature (23-24 PSPIAAIN).In fact, in this novel Sahgal deals with the problems of communication among the secluded elite of Delhi in terms of an artistic construct. The core theme of the novel is stated from the point of Rakesh who is himself uncertain, vacillating anxious and hesitant at the beginning. 
In terms of experience placed before us in this novel, it is recommended that end of tension and the gaining of self confidence and identity are possible only in an ambience of freedom. Freedom is seen to be an indispensable prerequisite for human development. Every major characters in this novel endeavour towards realisation of freedom as a basic human value. Rather than passing judgement on these characters, Nayantara Sahgal depicts them with sympathy and understanding. As A.V.Krishna Rao observes, "The growth and development of the individual consciousness of Rakesh, as well As that of kalyan, is the measure of the artistic achievement of Mrs. Sahgal",(32TTM) In This Time of Morning.

Sahgal is less concerned with the political system than with the people behind it. She portrays that the political "analyst prefer to talk about what is wrong with systems as if systems were made of nuts and bolts instead of people." $(2 \mathrm{Ca})$. It is this disposition that helps her in attaining and accomplishing the rare feat of accomplishing politics with novel writing. Though her political writings are significant, as Jasbir Jain notices, "it is a novelist that she is able to project a comprehensive view of life. Her novels express both her involvement with politics and the men and women behind political ideas and actions."(18NS)

If A Time to be Happy observes freedom carrying through life in all spheres, This Time of Morning depicts Nayantara Sahgal's growing disenchant and disillusionment. It deals with the post-Independence generation, for whom freedom is no longer a dream, but the reality confined by the bifurcation and blood-shed, the refuge issue and the assassination of Mahatma Gandhi. Besides this blood dimmed tide, there is the threat of the deterioration of the democratic structure caused by the conflict of values which the novelist portrays with unswerving concern for a human engendering. The administrative system still functions through the British framework and India finds herself burdened with an alien system of education and values.

The importance of Gandhian attitude and viewpoint are seen in Kailas, Abdul Rahman Prakash Sukla - people of elder generation. But they are a generation on disappear and are being discard and rejected as 'old fossils' of that fast waning generation which is "saddled with philosophy instead of common sense."(89TTM). The Post Independence approach is personified by people like Somnath and Hari Mohan. They stick to the Gandhian principles in the name only, because the spell work of Gandhi's name still gets to them votes. Money and power are their aims. Sacrifice and service are an abomination. This perspective finds farcical expression in Vishnu, the son of the unscrupulous civil servant, Dhiraj Singh. As a student at Oxford Vishnu spent more time on amusement, pleasure and celebration than on intellectual pursuits. He has "an avowed allergy to work".(99TTM) and he develops pragmatic tendency. He believes that the world owes him a living. Kalyan symbolises a third approach. He is a class by himself. He is mysterious. Like somnath he has a distain for Gandhian philosophies and values. But he differs from that group, at least, in his service and sacrifice. He is not a headhunter or career-hunter like Hari Mohan and Somnath. If he is offered the opportunity to lead the embassy and delegation to the U.N., it is just a reward for his contribution. He never sought it.

The sublime artistic skill of Nayantara Sahgal reveals itself in her tracing of the sources of Kalyan's crassness to the neglect he suffered and starvation he experienced in his childhood. He grew up "without the ordinary marks of identity" (74TTM) and torment from a sense of "terrifying anonymity". He remembers nothing about his past. He was found in a street in Patna during famine of 1914. He bethinks with agonizing clarity the famished, grotesque figure whom he called me and his pathetic effort to source food for her. The man who opened the door was astonished to find the single thread of life in the street of corpses. Kalyan watched his benefactor with " queerly glowing eyes of an animal at bay, one who would spring on a crust if it were thrown but would still keep his distance from his benefactor" (73TTM) his foster parents cogitated him a gift of the benevolent gods. Their statement exasperated his contempt for them. He had little regard for them because they lived and died without any fight. "They stagnated in the turgid water of their lives and gradually they rotted away"(75TTM). This traumatic experience of the childhood has dehumanised Kalyan.

Kalyan has a disdain for convention. Faith and comparison are empty words for him. This temperament results in his utter disregard for Gandhian principles. He disagrees with Gandhian fundamentals. As a man who has survived "all sort of famine - a famine of food and one of feeling".(66TTM).He cerebrates strategies of survival in cultivating the art of collectivisation and confederacy of intelligent group interests. The group can attain what the individual cannot. Hence Kalyan's significance is on the group to the neglect of the individual. He goes to the extent of saying that the society needs to be protected from the predatory individual.

Kalyan is ready to utilise men and deserted them as he discard his tools, without any uneasiness of conscience. He raises the question, "whose ego is so sacred that it must flourish at the expense of the community" (63TTM). In his distain and contempt for the individual, Kalyan forgets that group is a collection of individuals. For him individualism is 'rugged' and 'barbaric.' He promises by the group and deplores that there is not enough group effort or even awareness of its necessity in the society.

If kalyan's 'bright anger' against the world of the past brings about his dehumanization, his 'terrifying anonymity' consummates in his ruthlessness efficiency. Dehumanized as he is, work is the only outlet for him for expressing and demonstrating his identity. He is superintended by his overweening desire to leave his work on the work he chooses for himself. "There are two great motivating forces, it was said, love and hate. But he knew the third, the hunger for identity, and in his search for it he had never been able to tolerate one that challenged his own."(132TTM). hence he accomplishes his objectives in life, with a contumacious and monomaniacal concentration and pathological obsession. His mind is preoccupied with the torment of the disinherited 
masses. It is his strong conviction that "In India and in every newly independent country where time had stood still too long, things must move ahead or slide dangerously backward."(63TTM). This backward sliding can be prevented only when there is a sweeping, united movement.

Kalyan, the ruthlessly efficient and skilfully experienced pragmatist, calls the Gandhian belief of suffering bring about the catharsis of the spirit a bluff. In his perspectives suffering is an evil and sin which has to be rooted out and not to be sanctified. Hence during the freedom struggle he refused to join the congress which implied to him the indifference of long prison term. He went into self-imposed exile. He took assiduous and active steps in starting the Indian centre at Boston and educating people about India during the period of the freedom struggle. He finds two divergent attitudes in the society as well as politicians idealistic and materialistic.

Kailas on the other hand is dedicated and committed to the nurturing of the spirit of man. He believes that the human being is the measure of progress and ultimate concern in all our dealings. No course is so significant as to substantiate the sacrifice of individual, however humble he may be.

Kailas, drawing subsistence and sustenance from Gandhian philosophy and values, is foil to Kalyan. If Kalyan wants to bring about change through political power, Kailas wants to do so through the human heart. Having staked everything on the value-system of means, Kailas has perceived that there cannot be any short cut to progress. Social dynamic become significant only when the human being is not yet by-passed. He believes that even with all the will and cooperation in the world. "The slow way was the only human way."(18TTM). Economic and factories plans are not an end in themselves. In the world of Abdul Rahman, a colleague of Kailas, things in themselves are insufficient without human intentness and they ultimately stand "like abandon human habitation in the desert"(212TTM).

In despite of his association with Hari, Kalyan is not the man of his like. Kalyan is an unconventional. He never submits to any party discipline. Estranged from Indian sentiments and committed to progress, he is forced to seek coalition with Hari Mohan. It is based on the cooperation and convenience rather than confidence and conviction. Hari, with his conscience, pragmatism combined with money and power, becomes the best choice for kalyan.

Kalyan's other associates, Somnath, considers that running a government is different from leading the freedom struggle. The congress must attempt to become a political party like any other in order to achieve success. This group believes that unless official policies and administration are changed and faith in non-violence shed, the country cannot extricate itself from its colossal post-independence problems. But Kailas thinks that the party should not discard its moral character which is its major strength. Any change involving the deterioration of moral values will be self selfdefeting, according to him. The chumminess of Kailas, Abdul Rahman and Prakash Sukla is found is founded on this principle. While forming a coalition with Somnath and Hari, Kalyan thinks thus, "Allies need not trust each other and they were seldom friends, but they served each other's
purpose"(83TTM). This misalliance can survive only as long as the agreements are mutually beneficial. Hence Kalyan gives contract of the Peace Institute to Hari's son Ram Mohan, at high rates of commission. Ignoring the protocol and the recommendation of Arjun Mitra, Kalyan appoints Dhiraj Singh, a man doubtful dubious integrity, as the Director of the Peace Institute. Dhiraj has an inclination for wealth and luxury which make him not only corrupt but also immoral. Kalyan accedes his favours on such men as Dhiraj and Hari whose names have become tantamount with institutionalised corruption. They are not only immoral, but what is worse, their view is that morality is not relevant. They felicitate themselves on availing themselves of the opportunities that come their way. Kalyan has a 'subtle, intellectual' hold on the youth. His discussion group help Kalyan to extract 'blind loyalty' from them through charisma of his personality. Kalyan represents a type of enslavement brought about by means of personal charisma. His recommendation, the resultant pregnancy and sense of shame make leela suicide.

Jeevan, that slim, active and acute publisher of that single sheet of paper called 'The Wayfarer' comes under the spell of Kalyan. His paper as well as his body grows bulk. He becomes pleasantly placid and feels obliged to blow the trumpet of his patron,Kalyan. Nita is another character who becomes the impressionable to Kalyan's influence. In her we find a young woman whose desires both spiritual and sexual have not been understood by her parents. Despite their anglicised behaviour, Nita's parents are characterised as conformists. Her father retains the right of selecting a husband for her. Instead of upholding self expression, he turns back to custom. Nita's westernization makes her inwardly refuse to accept her father choice and outwardly accepts her father's decision. Her struggle against custom is depicted through her interior monologue. It is humiliating to be depraved to the status of a capital investment fund.Hence her outburst: "Stocks and shares, money and clothes. What about her body and its desire, she wanted to cry out, the body that pulsated for something with an urgency she had never known? (149TTM).

Yet she knows that she has to accept the stipulation and give "herself up to the game of pretence" (150TTM). In accepting in custom Nita, like Sahgal herself, realises that the demands of society are stronger than the desire of a protesting individual who eventually must capitulate to the collective desire of the community. Yet she demurs the slighting of her individuality. When Kalyan employs her, Nita's longing for pining away her own identity is fulfilled. She feels highly grateful to Kalyan. She is disinclined to include Triloki Nath in her personality page for the weekly magazine 'The Wayfarer' just because he is a scathing critic of Kalyan. She is blindly devoted to Kalyan that she thinks "what she did here in this office was an offering to Kalyan...it would be disloyal to him to give space to a man like Triloki Nath"(129TTM). This blind devotion, this hero worship, is depicted as contrary to the spirit of freedom. 
Nayantara Sahgal's prime concern in this novel is perfect and proper relationship between in public life as well as personal life. She is highly and remarkably critical of the pursuit of selfish ends and exploitation. People like Kalyan, who have rebuffed emotion as a superfluous indulgence, cannot work alone. They seek for coalition which is based on the comfort and convenience and not on the creed, morality and loyalty. Such a coalition cannot last ultimately. It "carriers embedded in it from the start the seeds of destruction" (p184 TTM). This is what exactly happens between Somnath and Hari Mohan. Their uncontrolled ambition leads to rivalry which eventually ruins them. Kalyan too falls with Hari Mohan. At the personal level, the failure of the Nita's marriage a predestined conclusion since in setting this alliance with Vijay's family is mainly concerned with monetary benefits and not Nita the individual. Hari Mohan is the opportunist and chief exploiter. In the beginning Hari desires to win the friendship of Kailas as he knows Kailas would be a great 'catch' for him. When his endeavours fail, he turns to Somnath. He owes his accomplishment to Somnath. Yet this immoral, Machiavellian exploiter tries to remove Somanth from power. That such exploitation is both destructive and selfdestructive is what this novel reveals.

For Kalyan benevolence, easygoing natures, the consequential talk that flow out of intimacy are alien to his temper. Even in love he fails to relate himself meaningfully to any woman and hence he remains a bachelor. The love Barbara and Celia for Kalyan leaves him as he is barren, reticent and dehumanised. Yet Kalyan is not utterly discredited. In This Time of Morning, Nayantara Sahgal deals with the problems caused by a changing order. "A new order replaces the old consequently causing disorder not only in the physical environment, but also in the psychological realm. The new philosophy 'calls all in doubt' including one's own identity and roots."(TTM7) Sahgal uses the urban setting and deals with the collapse of moral values in the civilised world. Sahgal deeply involved in the 'here and now' of modern India. The city of Delhi is still a city groping in the dark suffering from blankness and indistinct ion. Paris is France and London is London, but Delhi is just Delhi, and not India. Here political ambition and new fortunes choke ordinary values associated with urbanization. Out of this creative matrix arises the urban novel which Nayantara Sahgal has shaped. The world of Kailas is the moral world, a world grounded in our cultural heritage and which moves at its own leisurely pace. In Kailas's perspective freedom has to be nurtured with care and patience like young trees which 'grow in their own time.' But Kalyan world is the modern world based on ruthless competitiveness. In this 'time-bound existence' everything is at stake if we don't catch up fast. Personal freedom and sensitivity find no place in his scheme of values. His American education and his long stay at Boston "had lent the pragmatism to his outlook that had resulted in the search for dynamic rather than Gandhian men to serve his cause." Rapid urbanisation takes corruption in its stride. Hence Kalyan fails to understand the mayhem rose against the appointment of Dhiraj Singh as the Director of the Gandhi Peace Institute. He cannot comprehend it and wonders "If Dhiraj Singh were upright enough to be additional secretary in the external affairs and ambassador to Norway before that, why should he not be Director of the Institute?" (TTM.217)

Shagal feels that with Nehru that urbanisation is an inevitable process. Her novels show how growing urbanisation and indistinct ion become the lot of the average man. In Sahgal's opinion it is elite - educationists, civil servants, industrialist, parliamentarians and journalists - and their attitude to the average man that matters much. Since the vast majority of the people are illiterate and ignorant, this elite shapes their fate and can make or mar the nation. This novel offers a detailed analysis of the political scene in a changing era with its clash of values. This changing political scenario is delineated in terms of the creative configurations sustaining opposing view-points. Sahgal ardently desires that concern for the progress and concern for the individual should become complementary rather than contradictory. It is this desire that finally makes her humanise Kalyan through the agency of Nita's love. While other women are irresistibly drawn towards him against their better judgement, Nita alone comes to him freely. She consciously drops at his residence. She takes interest in decorating his house and in setting in order. This voluntary work on her part while he holds office may not be strange. But she comes even after his fall. Fearing scandal he questions the propriety of her visits. She feels deeply hurt. She says there is some inner compulsion which makes her come to him. This is because, of all the people she knows, he alone has given her freedom. This is the relationship based on recognition of each other's individuality.

There is no endeavour here to use one another for convenience. Kalyan's whole being responds to this relationship in peace and tranquillity, even as he stands in the shadow of defeat. 'The past enterprises' and the torture of loneliness to come' do not trouble him any further. Mrs. Nayantara Sahgal's creative sensibility achieve an ironic moral vision in the novel when Kalyan losses political power but gains personal redemption. This novel lays stress on a dynamic, political principle aiming at the quest for an impersonal humanity.

Whereas Anand, as a creative writer, shows his humanism through protest, Sahgal's humanistic interest is revealed through her art of subtle evocations of history blended with fiction. M.K.Naik's charge against Sahgal's plots is that characters and action are not solidly grounded in significant political issues. He thinks that the fictional story of the middle class characters "fails to coalesce with the political plot." A more balanced judgement of This Time of Morning comes from K.R.S. Iyengar who says, Thisa Time of Morning is written with much greater ease and sophistication than its predecessor, and it can certainly claim to be one of the best political novels written by an Indian in English.

With the remarkable ingenuity Sahgal associates the Gandhi Peace Institute in a symbolic way with both the political and personal worlds. This memorial to Gnadhi is ironically directed by Kalyan who calls Gandhi an

Published By: 
'emasculator'. Dhiraj to whom ends and not means count much becomes its director while the real Ghandhian worker, Kailas, is disqualified for he is not practical. This symbolic " a symmetrical structure" of modern architecture, a sermon in stone, supposed to represent a step in educating the public towards making peace a reality ironically, has turned out to be a hot bed of acrimonious debates and conflict. With its depiction of the ideological strife between humanistic and pragmatic forces, as kai Nicholson observes, this novel is akin to ' a twentieth century Morality play.' But to stretch this analogy would be self-defeating, for Kalyan is not completely discredited, nor can be identified with bad. By juxtaposing the corruption and the idealism of the political world, the novelist only aims at providing an insight into the working politics. Under people like Kalyan and his coterie for whom the non human aspect is more important than human aspect, politics has degenerated. In order to prevent further deterioration of political values, the Prime Minister calls Kailas to power as he alone can retrieves the degenerating political situation in U.P. When Kails finally comes to power, humanity finally triumphs over the alliance of the consciences politicians like Kalyan, hari Mohan and Somnath. Gandhian as This Time of Morning visualises it gets saved in Indian politics. With the ultimate triumph of humanity in the personal as well as the political spheres and the fall of those distain humanity, the novel "projects a reality which is at once artistically satisfying and ethically vindicated."

\section{CONCLUSION}

Thus Nayantara Sahgal shows the social and political changes that took place in the independent india by representing the true political arena. Kailas and Kalyan represent the idealism and pragmatism respectively. She clearly pictures the clash of values of Nita and freedom of expression.

\section{REFERENCES}

1 Sahgal, Nayantara, This Time of Morning, New Delhi, Orient Paperbacks, 1970.

2 Kai Nicholson, A presentation of Social problems in the Indo-nglian and the Anglo-Indian Novel. Bombay: Jaico Publishing House, 1972.

3 A.V. Krishna Rao, Nayantrara Sahgal: A Study of her Fiction and Non-Fiction, 1954-1974. Madras: M. Sesshachalam \&co, 1976.

4 Nayantara Sahgal, "Crime and Punishment," Express Magazine, 20 July 1986.

5 Jasbir Jain, Nayantara Sahgal, New Dehli: Arnold Heinemann, 1976.

6 M.K. Naik, Dimensions of Indian English Literature. 1984.rpt. New Delhi: Sterling Publishers Pvt. Ltd.,1985.

7 K.R.S. Iyangar, This Time of Morning in English. Bombay: Asia Publishing House, 1973.

8 Ferosa Jussawala "Of Cabbages and Kings: This Time of Morning and Storm in Chandigarh," The Journal of Indian Writing in English.1977. 